\title{
Respon Jamaah Terhadap Khutbah Jumat Menggunakan Bahasa Arab
}

\author{
Ahmad Kurnia Sandi ${ }^{*}$, Dadan Suherdiana ${ }^{1}$, \& Muhamad Khoyin ${ }^{2}$ \\ ${ }^{1} J u r u s a n$ Komunikasi dan Penyiaran Islam, Fakultas Dakwah dan Komunikasi, \\ UIN Sunan Gunung Djati, Bandung \\ 2Jurusan Ilmu Komunikasi, Fakultas Dakwah dan Komunikasi, \\ UIN Sunan Gunung Djati, Bandung \\ *Email : abmadkurniasandi17@gmail.com
}

\begin{abstract}
Khutbah is one of the legitimate conditions of Friday worship which is obligatory for male believers who are righteous. What is conveyed in the sermon should be material that is easily understood by the congregation, but in reality researchers found the use of the Arabic-language Friday sermon as a whole found in the Assuada mosque. The purpose of this study was to find out how the attention, understanding and acceptance of pilgrims to the Friday sermon used Arabic in the mosque of Assuada. This study uses a method based on the S-O-R developed by Hovland. The estimation of the $S-O-R$ theory is then analogous to the sermon process whose implementation is a communication activity consisting of stimulus, organism, response. Collecting data through observation, interviews, and division of questionnaires. The results of this study indicate that sermons using Arabic have unfavorable effects for worshipers in understanding the material delivered by the sermon. In terms of the attention of the congregation is quite good because as a condition of Friday prayer, in terms of understanding most of the pilgrims do not understand the material of Friday sermons because they can not understand Arabic so that Friday worshipers are not good at receiving sermon material delivered by the preacher.
\end{abstract}

Keywords: response; jamaab; Friday sermon; Arabic

\begin{abstract}
ABSTRAK
Khutbah merupakan salah satu syarat sah dari ibadah Jumat diwajibkan atas kaum mukmin laki-laki yang akil baligh. Apa yang disampaikan dalam khutbah seharusnya merupakan materi yang mudah dipahami oleh jamaah, namun dalam realitasnya peneliti mendapati adanya penggunaan khutbah Jumat berbahasa Arab secara menyeluruh yang terdapat di masjid Assuada.Tujuan penelitian ini untuk mengetahui bagaimana perhatian, pemahaman dan penerimaan jamaah terhadap khutbah jumat menggunakan bahasa arab di mesjid Assuada. Penelitian ini menggunakan metode yang di dasarkan S-O-R yang di kembangkan oleh Hovland, Asusmsi teori S-O-R ini kemudian di analogikan dengan proses khutbah yang implementasinya adalah aktivitas komunikasi yang terdiri dari stimulus, Organisme, Respon. Pengumpulan datanya melalui observasi, wawancara, dan
\end{abstract}


pembagian kusioner. Hasil penelitian ini menunjukan khutbah menggunakan bahasa arab memiliki efek yang kurang baik untuk jamaah dalam memahami materi yang di sampaikan khotib. Dalam segi perhatian jamaah cukup baik karena sebagai syarat shalat jumat, dalam segi pemahaman sebagian besar jamaah tidak memahami materi khutbah jumat karena tidak dapat memahami bahasa arab sehingga jamaah shalat jumat kurang baik dalam menerima materi khutbah yang di sampaikan oleh khotib.

Kata Kunci : Respon, Jamaah, khutbah Jumat, bahasa Arab

\section{PENDAHULUAN}

Dakwah yang tetap bertahan dan senantiasa dilakukan pada setiap waktu telah ditentukan adalah dakwah melalui khutbah, Khutbah mengandung ulasan tabsyir dan tandzir yakni menyampaikan kabar gembira dan peringatan atau tarhiib dan targhiib yang artinya mengisyaratkan dan mengungkapkan (Ridwan,2001: 2)

Menurut sebagian ulama fiqih islam dalam bukunya syamsuri siddiq (1993:

45) khutbah merupakan uraian, keterangan dan pandangan yang mengandung aspek nasihat bersumberkan ajaran Islam dijiwai semangat ketakwaan yang dilaksanakan menjelang shalat jumat dengan syarat yang telah di tentukan. Khutbah mempunyai ciri-ciri tertentu diantaranya terletak pada tempat, waktu dan suasana, lebih penting lagi khutbah jumat berfungsi sebagai media pembinaan umat yang regular, normative dan efektif.

Salah satu media dakwah dalam agama Islam adalah melalui khutbah Jumat merupakan ritual ke agamaan yang memiliki jangka waktu yang relatif sering dilakukan yakni seminggu sekali. Khutbah Jumat dijadikan sebagai sarana untuk membangkitkan iman dan taqwa umat Islam khususnya kaum laki-laki wajib baginya menjalankan shalat Jumat.

Masjid Assuada Cijerah kota Bandung sejak berdiri hingga saat ini setiap khutbah Jumat menggunakan bahasa arab, padahal mayoritas jamaahnya kurang lebih 90\% merupakan orang-orang yang tidak paham terhadap bahasa arab. Hal ini tentu menjadi sebuah permasalahan bisakah khutbah Jumat itu dipahami dan dimengerti oleh jamaah jumat yang mendengarkanya. Padahal esensi khutbah itu berisi wasiat dan pesan-pesan moral keagamaan yang dibutuhkan umat untuk memupuk rasa ketaqwaanya. namun pada kenyataanya banyak jamaah Jumat yang tidak paham dengan bahasa Arab yang di sampaikan, karena itu dimungkin kan maksud dan tujuan pesan khutbah tersebut tidak dapat dipahami oleh jamaah Jumat. Seharusnya khutbah yang disampaikan itu menggunakan bahasa yang bisa dimengerti dan dipahami oleh para jamaah yang hadir dalam sidang Jumat tersebut. .

Pelaksanaan sholat Jum'at merupakan karakteristik miniatur masyarakat yang islami. sekaligus sebagai ciri khas dan karakter umat muslim sebenarnya. dalam sholat Jum'at diliputi dengan penuh pensucian, pengagungan dan ganjaran 
pahala yang tinggi.Maka, ketika adzan dikumandangkan maka setiap manusia segera bergegas menuju masjid dan sejenak meninggalkan segala bentuk aktifitas untuk melaksanakan sholat Jum'at.

Maka sangat rasional bila peserta Jum'at itu perlu mengerti kandungan dan isi khutbah. Itulah sebabnya sebagian ulama memandang boleh saja khutbah disampaikan dengan menggunakan bahasa yang dapat dipahami oleh jama'ahnya.Adapun, kalimat hamdalah, syahadat, sholawat dan do'a itu hanya sebagai kesempurnaan dalam khutbah. (Romli, 1996:225).

Ketika tujuanya adalah memberikan nasihat, maka nasihat ini tidak akan tersampaikan kecuali dengan bahasa yang mereka pahami, sehingga mereka menggunakan bahasa Arab karena itu adalah bahasa mereka.Itulah sebabnya para Nabi dan Rasul diutus sesuai dengan bahasa kaum mereka.

Bahasa yang digunakan dalam khutbah Jum'at seharus mengikuti bahasa jamaah supaya apa yang di dengarkan oleh jamaah dapat di mengerti, Apabila seseorang berkhutbah di hadapan jamaah yang berbahasa Indonesia, maka yang diharuskan baginya adalah berkhutbah dengan bahasa Indonesia. Namun yang terjadi di Masjid Assuada Cijerah Bandung khutbah Jumat yang dilaksanakan di sana memakai bahasa Arab dalam khutbah jumat, seharusnya bahasa yang digunakan adalah bahasa yang mudah di pahami oleh sebagaian besar jamaah Jumatan.

Pertama, lili sufiah (2006) dalam skripsinya yang berjudul "Respon Jamaah terhadap aktivitas khitobah yayasan pondok pesantren misyakul anwar" cibabatcimahi. hasil penelitian tersebut menemukan bahwa para jamaah mempunyai respons perhatian, pemahaman terhadap khitobah yang terjadi di yayasan pondok pesantren mysakul anwar cibabat-cimahi. Berdasarkan di atas penelitian peneliti hampir memiliki kesamaan mengenai Respon Jamaah terhadap khutbah beda nya kalau peneliti sebelumnya focus terhadap pesan yang di sampaikain ustadz cep toto dalam pengajian bulanan, sementara peneliti mengenai Respon Jamaah terhadap khutbah Jumat menggunakan bahasa Arab.

Kedua, cucu vivi pratika (2006) dalam skripsinya yang berjudul "Respon Mahasiswa Terhadap Pesan Dakwah dalam lagu Nasyid Opick" hasil penelitian tersebut menemukan bahwa respon para mahasiswa terhadap pesan dakwah dalam lagu nasyid opick, sementara peneliti mengenai Respon Jamaah terhadap khutbah Jumat menggunakan bahasa Arab apakah positif atau negative.

Pelaksanaan tersebut, diawali hampir sama dengan pelaksanaan sholat Jum'at pada umumnya. Diawali dengan adzan pertama lalu ada adzan kedua dan para jama'ah melakukan sholat qobla Jum'at. Namun bedaanya, setelah itu tidak dilakukan ceramah/khutbah yang sering kita lihat di masjid-masjid lain, disini cukup muroqqi membacakan do'a berbarengan dengan imam yang memegang tongkat sambil mengetukannya.

Respon merupakan kemestian dalam proses kegiatan dakwah secara universal. Keadaanya bukan hanya sekedar umpan balik (feed back) dan reaksi penerima 
informasi terhadap pesan. Tetapi juga sangat menentukan sukses atau tidaknya suatu komunikasi.

Sehubungan dengan hal diatas ada beberapa komunikasi yang berkaitan dengan respon jamaah terhadap kegiatan dakwah, yakni bagaimana perhatian, pemahaman dan penerimaan jamaah terhadap khutbah jum'at yang menggunakan bahasa Arab di Masjid Assuada dalam proses komunikasi berkenaan dengan perubahan sikap adalah aspek How bukan What dan Why. Jelasnya How to communicate dalam hal ini How to change the attitude, bagaimana mengubah sikap komunikasi (effendi 225: 1779)

Berdasarkan pengertian respon yang diartikan (Onong Ucjhana Effendy 2003: 254) bahwa respon adalah sikap atau prilaku seseorang dalam proses komunikasi ketika menerima suatu pesan atau prilaku seseorang dalam proses komunikasi ketika manenerima suatu pesan yang ditunjukan kepadanya. Untuk mengetahui lebih jelas tentang respons, kita harus mengetahui tentang sikap ma'rifat dalam bukunya, sikap manusia perubahan serta pengukurannya. (26-27) mengutip pendapat Hovland, jenis dan killy yang mengatakan bahwa dalam pengertian dan penerimaan (Rafsanjani : 8)

Maksudnya komunikan akan memberikan jawaban atau reaksi kepada komunikator. Dengan adanya respons akan memainkan peranan yang amat penting dalam komunikasi, hal ini disebabkan kepada proses berlanjutnya komunikasi atau berhentinya komunikasi yang dilancarkan oleh komunikator. Oleh karna itu respons atau umpan balik dapat bersifat positif atau negativ.

Pertama espon positive merupakan tanggapan atau reaksi komunikan yang menyenangkan komunikator sehingga berjalan dengan lancar, kedua Sebaliknya respon negative adalah tanggapan komunikan yang tidak menyenangkan komunikannya sehingga enggan untuk melanjutkan dalam komunikasi. Hal begitu pentingnya respons atau umpan balik dalam proses dialetika antara komunikator dengan komunikan atau penerimaan pesan.

Dalam proses dakwah, bentuk interaksi psikologis antara dai dan mad'u ada dua teori sebagaimana yang dijelaskan. Didi munadi ardi dalam bukunya psikologi dakwah (2002: 55) yaitu teori behavioristik dan teori holistic. Teori behavioristic menjelaskan :

Bahwa mad'u menerima stimulus melalui receptors atau panca inderanya disampaikan kepada otak yang kemudian diteruskan melalui effector atau saraf, otot, kemudia persendian sebagai pelaksanaan gerak. Saat intulah mad'u mengikuti proses dakwah, yakni merespons stimulus yang berupa pesan da'i.

Jamaah menurut bahasa Arab, kata jama'ah berasal dari kata dasar jama'a atau mengumpulkan yang berkisar pada al-jam'u atau kumpulan, al-ijma atau kesepakatan, dan al-ijtima atau perkumpulan yang merupakan lawan kata dari attaffaruq atau perpecahan. Ibnu faris berkata ' Jim, mim dan ain adalah satu dasar yang menunjukan berkumpulnya sesuatu, singkatan jama'tu asya'a jam'an yang berarti saya mengumpulkan sesuatu.

Sedangkan menurut istilah para ulama aqidah, kata “jamaah adalah generasi 
dari umat ini, meliputi para sahabat nabi, para tabi'in dan semua orang yang mengikuti mereka dengan baik sampai hari kiamat. Mereka adalah orang yang bersepakat untuk menerima kebenaran yang nyata daei Al-Quran dan as-Sunnah. Menurut bahasa arab pengertiannya adalah dari kata al-jamu dengan arti mengumpulkan yang bercerai-berai. Sedangkan dalam kamus ilmiah popular jamaah adalah sekumpulan orang atau sekelompok manusia (kamus ilmiah popular, 2006: 282)

Khutbah jumat Secara etimologis (harfiah), khutbah artinya pidato, nasihat pesan (tausiyah) sedangkan menurut terminology (istilah syara) ialah pidato yang disampaikan oleh seorang khatib di depan jamaah dilaksanakan dengan syaratsyarat dan rukun tertentu menurut kamus besar bahasa Indonesia (1999:489) khutbah berarti pidato.

Khutbah jumat merupakan pidato yang disampaikan sebelum shalat jumat dilaksanakan. Sesungguhnya khutbah jumat merupakan kesempatan yang sangat besar untuk berdakwah dan membimbing manusia menuju keridhaan Allah. Hal itu jika khutbah dimanfaatkan sebaik-bainya, dengan menyampaikan materi yang dibutuhkan oleh hadirin menyangkut masalah agama mereka, dengan ringkas, tidak panjang lebar, dan dengan cara yang menarik serta tidak membosankan sebagaimana di contohkan oleh Nabi Muhammad SAW.

Shalat Jum'at harus disertai dengan khutbah oleh khatib. Syarat khutbah Jum'at adalah sebagai berikut: (1) Niat. (2) Suci dari hadas besar dan najis, (3) Khotib Harus menutupi aurat, (4) Khatib dimulai setelah masuk waktu shalat Dhuhur, (5) Khatbah dilakaukan dengan berdiri, (6) Khatib duduk sejenak antara dua khutbah, (7) Mengangkat suara sehingga terdengar makmum, (8) Disampaikan dengan bahasa yang bisa dipahami oleh jamaah, (9) Antara kutbah satu dan khutbah dua dilakukan dalam satu waktu (Widiatama 2015: hal 88). Adapun rukun khutbah adalah pertama memanjatkan pujian kepada Allah. Kedua, bershalawat pada Nabi Muhammad saw. Ketiga, menyampaikan pesan takwa kepada Allah SWT. Keempat, mendoakan kaum muslimin, dan yang kelima adalah membaca beberapa ayat al-Quran

Tujuan dari khutbah jumat adalah untuk memberikan pengetahuan dan pemahaman terhadap ayat-ayat yang terdapat dalam Al-Quran dan hadits yang di sabdakan Rasulullah sebab, di dalam keduanya itulah terdapat pedoman dan petunjuk hidup umat muslim dalam mengarungi kehidupan agar senantiasa dijalan yang lurus (2003: 21)

Hal lain yang menjadi ciri khas khutbah jumat adalah sesuai dengan nama harinya sehingga akan senantiasa teratur peristiwanya dan lebih sering kejadiannya jika dibandingkan khutbah yang lain. Selain itu, jika diamati lebih cermat khutbah jumat juga mempunyai keistimewaan yaitu, terdiri dari dua bagian. Khutbah bagian pertama pada umumnya berisi materi utama yang dikhutbahkan dengan disertai data, fakta, analisis, sejarah, dan ayat-ayat Al-Quran atau hadist. Khutbah bagian kedua biasanya berisi kesimpulan dan penekanan dari khutbah tersebut

Bahasa merupakan suatu cara komunikasi yang bisa memberikan pengaruh 
langsung bagi kedua belah pihak, penutur dan lawan bicaranya. Bahasa sebagai alat komunikasi berfungsi menyampaikan pesan dari penutur (komunikator) kepada mitra tutur (komunikan).

Terdapat dua macam komunikasi bahasa yang terjadi antar manusia dalam masyarakat, yaitu komunikasi searah dan komunikasi dua arah. Abdul Chaer dan Leonie Agustina, (2004: 21).

Semulya-mulyanya berjuang di jalan Allah SWT. pasti selalu ada hambatanhambatan yang menerpanya. Baik hambatan yang bersifat internal, maupun hambatan yang bersifat eksternal. Hambatan internal yaitu hambatan yang muncul dari dalam diri sendiri, terdiri atas: pertama hambatan lahir, dan kedua hambatan bathin. Hambatan lahir diakibatkan karena beberapa hal, yakni: (a) karena kesibukan dengan urusan duniawi, (b) adanya pengaruh dari luar, baik secara individu atau kelompok tertentu, dan (c) dukungan keluarga yang belum sejalan. Sedangkan hambatan bathin adalah paling tidak disebabkan karena tidak menjaga dan mengamalkan amalan infirodi yang disingkat " 5 " yakni: pertama Tidak melaksanakan takbiratul ula (shalat tepat waktu), kedua Tidak melaksanakan shalat tahajud, ketiga Tidak mendawamkan tilawatil quran, keempat Tidak melaksanakan tasbihat dzikir di pagi hari, siang dan malam hari, dan kelima, Tidak menundukan pandangan dari perbuatan maksiat.

Sebelum merespon, mad'u sesungguhnya telah memiliki kesiapan pada dirinya dalam dua hal : tujuan mengikuti proses dakwah dan motivasi yang menggerakan untuk mengikuti proses dakwah sesuai dengan kebutuhannya secara interistik maupun ekstrinsik. Formula respons mad'u terhadap da'I (khotib) atau dikatakan sebagai prilaku mad'u, dapat dijelaskan sebagai berikut : mad'u menerima materi-materi dakwah yang disampaikan oleh khotib melaui receptors atau panca indera. Materi itu disampaikan ke otak. Dalam otak terjadilah proses penyadaran, apakah sesuai dengan tujuan mengikuti dakwah, dan apakah dapat memuaskan kebutuhannya. Dari sana diteruskan melalui effector atau saraf, otot, kemudian persendian sebagai pelaksana gerak. Agus Mubarak, MA dalam buku Psikologi dakwah (1999: 26) mengatakan ketika seorang dai berpidato diatas mimbar maka suara, materi dan gaya berbicaranya ditangkap oleh panca indera hadirin, dan ketika ada jamaah yang bersalaman dengan tangan da'I tersebut, maka kehalusan tangan kulitnya dapat diraba oleh indera hadirin.

Oleh sebab itu bisa disimpulkan bahwa teori S-O-R (stimulus-OrganismeResponse) dalam proses komunikasi yang berkenaan dengan perubahan sikap, dalam arti bagaimana seorang komunikator merubah suatu sikap seseorang atau kelompok, sehingga hal tersebut merupakan stimulus yang digambarkan sebagai pemahaman, pengertian, penerimaan dan kesadaran. Elemen-elemen dari model ini adalah pesan (stimulus), komunikan (organism) dan efek (respons) teori ini dapat dijelaskan dengan gambar sebagai berikut.

Berdasarkan latar belakang diatas, penulis tertarik untuk mengadakan penelitian mengenai " Respons Jamaah terhada Khutbah Jumat menggunakan Bahasa Arab 
(Studi kasus di Mesjid Assuada Gg. Pesantren RT06 RW06 Cijerah Bandung Kulon,

Penelitian ini berlokasi Masjid Assuada Cijerah Kota Bandung Jl. Cijerah Gg. Pesantren RT 06 RW 06. Adapun pertanyaan penelitian ini adalah; pertama, bagaimana perhatian jamaah terhadap khutbah jumat menggunakan bahasa arab? Kedua, bagaimana pemahaman jamaah terhadap khutbah jumat menggunakan bahasa arab? Ketiga, bagaimana penerimaan jamaah terhadap khutbah jumat menggunakan bahasa arab?

Adapun metode penelitian yang digunakan adalah kuantitatif deskriptif yaitu bermaksud untuk melakukan penyelidikan, menuturkan, menganalisa, mengklasifikasi dan menafsirkan data-data serta menginterpretasikan arti data dalam bentuk hubungan, pandangan, atau kecenderungan yang nampak. Adapun populasi dan sampel yang diambil dalam penelitian ini sebanyak 21 orang. Ini dikarenakan menurut Suharsimi Arikunto bila populasi meliebihi dari 100 orang maka sampel bisa diambil 10\%-15\% dan 20\%-25\% atau lebih sesuai dengan kemampuan peneliti tapi jika populasi 100 atau kurang maka sampel bisa ambil secara keseluruhannya.

Berdasarkan hal tersebut, maka penulis mengambil sampel 20\% dari 150 mad'u yakni 30 mad'u dengan cara provorsive sampe (sampel bertujuan) adalah teknik pengambilan sampel berdasarkan pada tujuan tertentu dengan memperhatikan ciri-ciri dan karkteristik populasi. Dengan demikian peneliti mengambil sampel sesuai dengan usia dan kemampuan ingatan serta keatifan dalam kegiatan sehari-hari. Adapun teknik pengambilan data menggunakan teknik observasi dengan cara mengikuti kegiatan shalat jumat di mesjid Assuada Cijerah Kota Bandung. Peneliti juga menyebarkan angket atau kuisioner kepada para mad'u dalam kegiatan khutbah jumat .

Rumus yang digunakan dalam penelitian ini atau pengambilan data adalah :

$\mathrm{P}=$ besar presentase

$$
P=\frac{F}{N} \times 100 \%
$$

$\mathrm{F}=$ frekuensi responden

$\mathrm{N}=$ jumlah responden

Namun peneliti akan mengambil jumlah rata-rata yang terdiri dari lima pertanyaan yang ada di dalam kuosioner. Untuk memudahkan dalam hal penafsiran data serta dapat membantu dalam menentukan jumlah rata-rata dari keseluruhan pertanyaan yang diajukan kepada para responden atau jamaah Masjid Assuada Cijerah Kota Bandung.

$\mathrm{X}=$ mean

$$
X=\frac{\sum P}{n}
$$

$\mathrm{P}=$ presentase terbesar

$\mathrm{n}=$ jumlah soal 


\section{HASIL DAN PEMBAHASAN}

Masjid Assuada didirikan pada tahun 1916. Pendirinya adalah KH Muhammad Adro’i, beliau merupakan salah satu ulama dan sebagai sesepuh di kelurahan Cijerah. Beliau dibantu oleh Shofian Anwar selaku Camat Cijerah dan H. Usman selaku Lurah Cijerah. Selanjutnya, pembangunan masjid dibantu oleh seluruh warga sekitar. Adapun status tanah dari masjid ini adalah tanah milik KH Muhammad Adroi yang diwakafkan untuk di bangun nya masjid Assuada, karena beliau bertujuan membangun masjid Assuada ini menjadikan masyarakat yang islami di daerah tersebut.

Tidak mudah perjuangan untuk mendirikan Masjid Assuada di Cijerah Gg. Pesantren RT06 RW06 Kecamatan Bandung Kulon. Banyak sesepuh kelurahan Cijerah terdahulu yang menentang pembangunan masjid yang kedua di kelurahan Cijerah ini, yang sebelumnya memang sudah ada satu bangunan masjid di kelurahan Cijerah yang berada di tempat yang berbeda. Para sesepuh dari kelurahan yang lain berbeda pendapat tentang akan dibangunya masjid ini. Mereka tidak setuju dan beradu argumen, sampai membuka dan membacakan kitab- kitab yang pernah mereka pelajari, menurut para Jumhur ulama yang menjadi dasar pegangan mereka. Karena memang sebagian para ulama ada yang mengatakan dalam sebuah kelurahan tidak dibolehkan ada bangunan masjid lebih dari satu. di karenakan nanti dalam melaksanakan shalat terutama shalat jumat, shalatnya tidak Sah. ada juga yang berpendapat boleh, karena alasan tertentu. Oleh karena itu para sesepuh kelurahan Cijerah bersitegang karena masalah itu. Tetapi akhirnya sesepuh dari kelurahan Cijerah menemukan pendapat dari Jumhur ulama dan mampu menerangkan dengan baik tentang dibolehkanya mendirikan masjid lebih dari satu dalam sebuah desa atau kelurahan untuk alasan tertentu dan memenagkan perdebatan itu, dan akhirnya menjadi kesepakatan bersama untuk mendirikan masjid yang diberi nama Assuada.

Sebelum berdirinya bangunan Masjid Assuada yang ada di Cijerah Gg. Pesantren RT06 RW06 kecamatan Bandung Kulon ini, warga banyak yang tidak menjalankan ibadah shalat berjamaah. Karena memang dulu di Cijerah sudah ada Masjid tetapi tempatnya jauh dari warga gang pesantren Cijerah. Banyak warga yang malas untuk pergi beribadah ke masjid. Karenakan juga SDM warga memang rendah, terutama dalam masalah pendidikan dan agamanya. Setelah Masjid Assuada yang ada di cijerah Gg. Pesantren RT06 RW06 kecamatan Bandung Kulon ini berdiri, banyak warga yang antusias dan mau pergi ke Masjid untuk beribadah. dan semakin lama semakin banyak warga yang datang ke Masjid sampai sekarang ini. Itulah sekilas tentang gambaran sejarah berdirinya Masjid Assuada yang berada di Cijerah Gg. Pesantren RT06 RW06 kecamatan Bandung Kulon

Pada awal pendiriannya masjid Assuada di bangun padatahun 1916 di Area tanah seluas 25 x 10 meter pajang 25 meter lebar 10 meter keseluruhan luas tanah 250 meter dan keseluruhan pembangunan masjid Assuada rampung pada tahun 1919 tokoh utama pembangunan masjid Assuada ini adalah KH. Adroi beliau 
adalah orang yang mewakafkan tanah untuk pembangunan masjid Assuada

Masjid ini terbagi menjadi tiga ruanganya itu depan, belakang dan sebelah kanan kondisi masjid saat ini bersih dan terawat karena ada perombakan yang dilakukan oleh pihak DKM Masjid Assuada dengan perombakan tembok yang retak diperbaiki, pengecetan ulang maupun tembok ataupun pagar Masjid, perbaikan atap yang mulai rapuh maka dari itu Masjid Assuada terawat dengan baik.

Ruangan Masjid terdiri dari : pertama, ruang ibadah Merupakan tempat shalat dengan lantai parquet yang bersih dan bergaris-garis untuk shaf (barisan shalat), podium atau mimbar yang enak bagi khatib, mhrab imam, ruang pengaturan sound system dan ruang perpustakaan. Kedua, ruang wudlu dan toilet Sudah jelas bahwa masjid mutlak harus menyediakan ruang untuk berwudlu dan toilet, dikarenakan tempat wudlu itu mempunyai beberapa keutamaan dan tempat menghilangkan dosa-dosa, selain itu orang yang melakukan ibadah shalat bukan hanya jamaah atau masyarakat yang berada disekitar masjid tersebut. Ketiga ruang secretariat dan perpustakaan, kegiatan administrasi dan segala hal yang terkait dengan masjid pengelolaanya tentu memerlukan satu ruangan, ruagan ini disebut dengan secretariat atau kantor masjid dengan disatukan pepustakaan supaya secretariat atau ruangan tersebut bisa dipakai sambil berbaca dan berdiskusi. Keempat, ruang madrasah merupakan tempat menimba ilmunya para santri tingkat Diniyyah Takmiliyah Alwaliyah (TPA) . yang tempatnya bisa disebut ruangan serba guna dan kadang dipakai ruangan untuk pengrusan zakat, dan pernikahan. Kelima, gudang Masjid tentu saja harus memiliki ruang khusus untuk menyimpan barang-barang yang tidak terpakai atau pemakaianya sewaktu-waktu sehingga penempatan barang-barang seperti peralatan kebersihan dan sarana pun tidak sembarangan di simpan dimana saja. Ruangan khusus itu adalah gudang, adanya gudang sangat penting untuk membat masjid menjadi bersih dan teratur.

Dalam upaya menjalankan visi di atas dan pesan-pesan Al Qur'an dalam memakmurkan masjid, maka Badan Kemakmuran Masjid Jami' Assuada memiliki misi sebagai berikut : pertama memberikan pembinaan kepada umat muslim untuk meningkatkan kualitas iman dan taqwa kepada Allah SW'T dengan cara-cara yang sesuai dengan ajaran Al Qur'an dan Al Hadist. Kedua, turut serta dalam kegiatan-kegiatan amar ma'ruf nahi munkar. Ketiga, meningkatkan silaturahim antar umat muslim untuk mendorong kepedulian, kepekaan dan solidaritas umat muslim terhadap masalah-masalah kebangsaan dan umat dalam hal ekonomi, pendidikan, politik, hukum, sosial dan budaya. Keempat, menjadikan masyarakat sekitar menjadi masyarakat yang Islami. Kelima, kegiatan-kegiatan lainnya yang sejalan dengan ajaran Al Qur'an dan Al Hadist dalam upaya memakmurkan masjid sebagaimana yanng dicontohkan oleh Rasulullah SAW.

Kegiatan Masjid Assuada terdiri dari : pertama, Gamis Bequ (Gerakan Menunggu Isya Bersama Alqur'an )gerakan menunggu sholat isya bersama ini perlu di sosialisasikan ke berbagai musholla dan masjid-masjid di seluruh nusantara, karena selain nilai pahalanya yang sangat tinggi di sisi Allah SW'T, juga merupakan sebuah pembelajaran bagi generasi muslimin yang merindukan 
generasi Alqur'an, kegiatan ini bisa di isi dengan kegiatan pembelajaran baca tulis Al Qur'an, kajian islam, serta tasmi'ul qur'an, dan lain sebagainya. Kedua, majlis ta'lim Assuada ( Khusus Ibu - ibu dan remaja putri ). Pengajian dua pekanan untuk kaum ibu-ibu dan remaja putri di sekitar masjid Assuada, acara di isi dengan kegiatan tasmi'ul qur'an oleh hafidzoh-hafidhoh masjid nurul fikri, taujih serta siraman rohani oleh para asatidz asatidzah dengan meteri materi yang sangat di butuhkan kaum muslimin. Ketiga, Majlis Al Qur'an Mujahidah ( Khusus Ibu ibu ) Program pembelajaran Alqur'an yang di peruntukkan oleh kaum ibu-ibu yang tidak mampu, di tambah dengan motivasi-motivasi serta taujih dari para asatidzah. dalam pelaksanaan program ini, pengurus serta pembina juga membagikan beras bagi peserta kegiatan yang aktif dan di rasa kurang mampu. Keempat, TPA Assuada kegiatan pembelajaran alqur'an yang di ikuti oleh anak anak warga sekitar masjid nurul fikri, dibina dan dididik oleh para asatidzah yang telah lulus tashih program qiro'ati. Kelima, Peringatan Hari Besar Islam. Gebyar Muharram, Maulid Nabi Muhammad SAW, Isro' Mi'roj, Syiar Amaliyah Ramadhan, Idul Fitri, Idul Adha. Kelima, LTTQ Assuada Program pembinaan bagi para pemuda serta mereka yang bersemangat dalam mempelajari serta menghafal Al Qur'an, dibimbing oleh para Huffadz yang ada di Masjid Assuada. Keenam, Program Wakaf Al Qur'an Masjid Assuada mencoba memfasilitasi kegiatan wakaf alqur'an untuk di sebarkan ke masjid-masjid/pesantren-pesantren di seluruh indonesia. bagi kaum muslimin dan muslimat yang hendak mewakafkan alqur'an, dapat menyalurkannya melalui DKM Masjid Assuada, baik dalam bentuk uang tunai (untuk di belikan mushaf Al Qur'an) atau Mushaf Alqur'an. Ketuju, Mabit Bulanan, kagiatan ini di peruntukkan bagi pengurus masjid (Khususnya) dan kaum muslimin (umumnya), sebagai sarana peningkatan kualitas ruhiyyah, dan jasadiyyah.

Maka sangat rasional bila peserta Jum'at itu perlu mengerti kandungan dan isi khutbah.Itulah sebabnya sebagian ulama memandang boleh saja khutbah disampaikan dengan menggunakan bahasa yang dapat dipahami oleh jama'ahnya.Adapun, kalimat hamdalah, syahadat, sholawat dan do'a itu hanya sebagai kesempurnaan dalam khutbah.(A. Chodri Romli, 1996:225). Pada diri jamaah Jumatan pun demikian, proses self indicatin juga terjadi dalam keputusan jamaah Jumatan hadir dan mengikuti ibadah shalat Jumat di masjid Assuada dan mendengarkan khutbah tersebut. Hal tersebut dapat dilihat dalam hasil temuan data mengenai keputusan yang diambil para jamaah untuk menunaikan ibadah Jumat dan mendengarkan khutbah Jumat, jamaah mengaku tidak faham secara keseluruhan apa isi dari khutbah yang disampaikan oleh khatib, seperti jamaah anak-anak, mereka tidak mengetahui sama sekali arti dari khutbah Jumat tersebut, lain halnya dengan jamaah dewasa mereka sebagian besar mengetahui arti dari khutbah, namun hanya pada garis besarnya saja, seperti perintah untuk bertaqwa namun untuk materi yang disampaikan oleh khatib mereka tidak begitu paham dengan apa yang disampaikan dalam khutbah tersebut. 
Informan tersebut tidak lah diambil secara tiba-tiba dan langsung saja diaksanakan tanpa melalui berbagai pertimbangan, melainkan keputusan tersebut diambil melalui beberapa tahap dalam interaksi sosial yang dilakukan informan dengan individu lain, dimana sebelumnya para jamaah telah mengetahui dasar yang digunakan untuk melakukan khutbah bahasa Arab di masjid Assuada, serta mereka juga mengetahui berbagai pengetahuan dan penjelasan mengenai pelaksanaan ibadah Jumat berdasarkan ilmu fiqihnya yang telah mereka pelajari, lain halnya dengan jamaah anak-anak mereka kurang mengetahui dasar apa yang digunakan untuk menjalankan khutbah bahasa Arab. karena kurangnya pemahaman dan pengetahuan mereka tentang ibadah Jumat.

Bukti lain bahwa keputusan dalam melakukan dan menunaikan ibadah Jumat di masjid Assuada oleh para jamaah tidak terjadi terjadi secara langsung, mereka memahami bahwa penggunaan bahasa Arab merupakan hal yang sunnah dan dinilai baik untuk dilaksanakan di masjid Assuada, meskipun mereka tidak memahami apa yang disampaikan oleh khatib dalam khutbah Jumat tersebut, bahkan jamaah menilai penggunaan bahasa Arab daam khutbah Jumat di sana dirasa kurang sesuai karena mereka para jamaah banyak yang tidak tahu arti dari bacaan khutbah tersebut, namun meskipun begitu para jamaah tetap mengikuti ibadah Jumat di masjid Assuada karena dia mengikuti apa yang dilakukan para kiai disana yang menunaikan ibadah Jumat di masjid Assuada.

Dalam pandangan jamaah lainya, memilih memutuskan mengikuti ibadah Jumat dan semua informan lain diatas tetap memutuskan untuk menjalan ibadah Jumat di sana dan mendengarkan khutbah, karena adanya suatu hal yang mereka fahami, yakni faktor lokasi dekatnya masjid dengan lingkungan tempat bermukim mereka, karena dalam pemaham mereka menunaikan ibadah Jumat diharuskan ada 40 orang jamaah yang bermukim di sekitar masjid, sehingga mereka menafsirkan bahwa mereka lebih utama menunaikan ibadah Jumat di masjid yang terdekat yakni masjid Assuada, meskipun dalam khutbah Jumatnya mereka tidak bisa memahami apa yang disampaikan khatib.

Dari penjelasan di atas sangat jelas bahwa proses self indication juga terjadi dalam diri jamaah Jumatan di masjid Assuada Cijerah kota Bandung, karena mereka bertindak berdasar pemaknaan maupun pehamahan yang mereka peroleh dari interaksi dengan individu lainya dan dengan kemampuanya individu tersebut menafsirkan pengetahuan yang didapatnya

\section{Perhatian Jamaah Terhadap Khutbah Jumat Menggunakan Bahasa Arab di Masjid Assuada}

Perhatian merupakan reaksi umum dari organisme dan kesadaran yang menyebabkan bertambahnya aktifitas, daya konsentrasi, dan pembatasan kesadaran terhadap satu objek.

Dalam pengertian yang sempit, perhatian dianggap sebagai akibat dari kemampuan psikis yang disebut sebagai minat. Minat merupakan momen dari kecenderungan yang terarah secara intensif kepada satu objek yang 
dianggap penting. Minat ini erat kaitannya dengan kepribadian, dan selalu mengandung unsur afektif atau perasaan, kognitif dan kemauan. Jika minat dan perhatian ini begitu terabaikan, keadaan sedemeikian ini disebut sebagai "verstooid", absent minded atau minat yang tercecer. Melekat dan tercekam oleh satu objek itu disebut sebagai perverest. Perhatian dan minat ini ada kalanya tetap konstan, ada kalanya tidak konstan, karena selalu mengalami ayunan atau goyangan, yang disebutkan sebagai osilasi minat atau perhatian (Kartini Kartono, 1996 : 111-113).

Dari 5 butir pertanyaan yang sudah diberikan kepada para responden, hasil akhir yang diterima dari setiap jawaban yang tertinggi lalu dicari rata-ratanya antara lain

a) Persentase Soal Perhatian

$$
X=\frac{50 \%+53,3 \%+46,6 \%+60 \%+56,7 \%}{5}=53,32 \%
$$

Hasil yang diperoleh dari penyebaran angket dengan 5 pertanyaan yang berkaitan dengan segi perhatian sebanyak 53,32\% atau lebih dari setengahnya dari para Jamaah memberikan perhatian pada kegiatan khutbah Jumat ini. Faktorfaktor penyebabnya antara lain bahwa Perhatian jamaah terhadap khutbah jumat menggunakan bahasa arab di Masjid Assuada lebih dari setengahnya memperhatikan khutbah jumat. Hal ini disebabkan karena jamaah merasa membutuhkan apa yang di sampaikan oleh khotib, serta jamaah mengetahui bahwa mengikuti dan mendengarkan khutbah jumat merupakan salah satu syarat shalat jumat, walaupun sebagian jamaah yang tidak memberikan perhatian yang serius di karenakan tidak mengerti apa yang sampaikan oleh khotib. jamaah mengaku mengantuk pada saat berlangsungnya khutbah jumat serta jamaah juga asik mengobrol karena merasa bosan. Tapi sebagian besar jamaah yang mengantuk dan mengobrol, kemudian kembali berusaha berkonsentrasi dan tidak menganggu jamaah yang lainnya

Menurut Dahyono bahwa setiap individu yang lahir ke dunia dengan suatu hereditas tertentu. Ini berarti karakteristik individu diperoleh melalui pewarisan atau pemindaan cairan-cairan germinal dari pihak kedua orangtuanya, disamping itu, individu tumbuh dan berkembang tidak lepas dari lingkungannya (Dahyono 1997 : 120).

Sudah jelas bahwa kegiatan khutbah Jumat merupakan salah satu faktor untuk meningkatkan kesadaran beragama yang berasal dari luar diri sendiri atau eksternal. Lingkungan sekitar termasuk pertemanan, keluarga dan sosial cukup berpengaruh terhadap kesadaran beragama seseorang.

Sehingga dapat disimpulkan dari hasil diagram diatas bahwa lebih dari 
setengahnya jamaah memberikan perhatian dan respon yang baik pada kegiatan khutbah jumat ini.

\section{Pemahaman Jamaah Terhadap Khutbah Jumat Menggunakan Bahasa Arab di Masjid Assuada}

Pemahaman dari mad'u yakni para jamaah masjid Assuada terhadap khutbah jumat menggunakan Bahasa Arab, Hal ini harus ada karena pemahaman dapat menunjukkan bahwa paham atau tidak nya jamaah terhadap khutbah Jumat menggunakan Bahasa Arab, karna bahwasanya khutbah itu mengajak masyarakat untuk melakukan perbuatan yang ma'ruf dan menjauhi kemungkaran serta untuk meningkatkan keimanan dan ketaqwaan kepada Allah SWT

Maka dari itu untuk mengetahui seberapa jauh pemahaman jamaah Mesjid Assuada terhadap khutbah jumat menggunakan bahasa Arab, berikut ini adalah hasil perhitungan dan tabel tentang pemahaman para jamaah Masjid Assuada terhadap khutbah Jumat menggunakan bahasa Arab

Pemahaman dari mad'u yakni para Jamaah terhadap kegiatan khutbah jumat menggunakan bahasa Arab di Masjid Assuada cijerah Kota Bandung. Hal ini harus ada karena pemahaman dapat menunjukkan bahwa kegiatan khutbah jumat dapat memberikan kontribusi terhadap kualitas kesadaran bersama pada para Jamaah.

Dari 5 butir pertanyaan yang sudah diberikan kepada para responden, hasil akhir yang diterima dari setiap jawaban yang tertinggi lalu dicari rata-ratanya antara lain :

b) Persentase Soal Pemahaman

$$
X=\frac{56,7 \%+43,3 \%+56,7 \%+56,7 \%+66,7 \%}{5}=56,02 \%
$$




\section{Pemahaman Jamaah Terhadap Khubat Jumat Menggunakan Bahasa Arab}

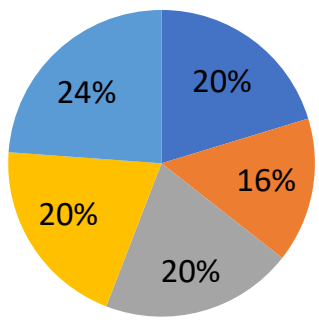

- Lebih Dari setengahnya (57\%)

Hampir setengahnya (43\%)

Lebih Dari setengahnya (57\%)

Lebih Dari Setengahnya (57\%)

Sumber : Hasil Penyebaran Angket

Hasil yang diperoleh dari penyebaran angket dengan 5 pertanyaan yang berkaitan dengan perhatian jamaah terhadap kegiatan khutbah jumat sebanyak $56,02 \%$ atau berarti para jamaah sebagian besar memiliki pemahaman yang kurang baik pada kegiatan jamaah. Pemahaman jamaah terhadap khutbah jumat menggunakan bahasa arab di Masjid Assuada, disimpulkan bahwa jamaah lebih dari setengahnya tidak memahami materi khutbah jumat yang disampaikan oleh khotib. Hal ini di karenakan pemahaman jamaah terhadap khutbah jumat menggunakan bahasa Arab yaitu rendah karena banyak masyarakat yang tidak paham tentang bahasa arab dan tidak menggunakan bahasa arab dalam kehidupan sehari-hari, serta menggunakan bahasa arab kurang dapat di pahami oleh sebagian besar jamaah shalat jumat, sehingga materi yang di sampaikan oleh khotib tidak dapat di pahami dengan baik.

Hal tersebut dapat dilihat dalam hasil temuan data mengenai keputusan yang diambil jamaah untuk menunaikan ibadah Jumat dan mendengarkan khutbah Jumat, meskipun semua jamaah mengaku tidak faham secara keseluruhan apa isi dari khutbah yang disampaikan oleh khatib, seperti jamaah anak-anak, mereka tidak mengetahui sama sekali arti dari khutbah Jumat tersebut, lain halnya dengan jamaah dewasa mereka sebagian besar mengetahui arti dari khutbah, namun hanya pada garis besarnya saja, seperti perintah untuk bertaqwa namun untuk materi yang disampaikan oleh khatib mereka tidak begitu paham dengan apa yang disampaikan dalam khutbah tersebut

Menurut W.H Tomas bahwa yang menjadi sumber kejiwaan agama adalah keinginan dasar yang ada di dalam diri manusia, yaitu: keinginan untuk keselamatan, untuk mendapat penghargaan, untuk ditanggapi dan keinginan terhadap pengetahuan dan pengalaman baru. Dengan melalui ajaran agama yang teratur, maka keinginan tersebut dapat tersalurkan. Dengan mengabdikan diri 
kepada Tuhan, maka keinginan untuk keselamatan akan terpenuhi, sedangkan pengabdian terhadap Tuhan menimbulkan perasaan menyintai dan dicintai Tuhan. (Rahmat, 1998: hal 209)

Sehingga dapat ditarik kesimpulan dari diagram yang sudah dipaparkan bahwa lebih dari setengahnya jamaah kegiatan khutbah jumat ini memiliki pemahaman yang kurang baik terhadap khutbah yang di sampaikan oleh khotib

\section{Penerimaan Jamaah Terhadap Khutbah Jumat Menggunakan Bahasa Arab di Masjid Assuada}

Penerimaan diukur sejauh mana jamaah menerima, menyetujui dan mendukung terhadar khutbah jumat menggunakan bahasa Arab Berikut ini adalah penerimaan Jamaah khutbah jumat menggunakan Bahasa Arab, dalam hal ini meliputi bagaimana penerimaan bagaimana persetujuaan jamaah terhadap khutbah jumat menggunakan bahasa arab baik dari pesan yang di sampaikan oleh khotib

c) Persentase Soal Penerimaan

$$
X=\frac{63,3 \%+40 \%+40 \%+46,7 \%+43,3 \%}{5}=46,66 \%
$$

\section{Penerimaan Jamaah Terhadap Khutbah Jumat Menggunakan Bahasa Arab}

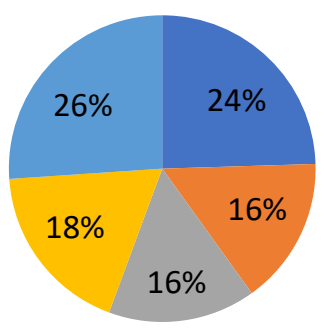

- Sebagian Besar (63\%)

- Hampir Setengahnya (40\%)

hampir Setengahnya (40\%)

hampir Setengahnya $(47 \%)$

Sumber : hasil penyebaran angket

Hasil yang diperoleh dari penyebaran angket dengan 5 pertanyaan yang berkaitan tentang penerimaan jamaah terhadap kegiatan khutbah jumat sebanyak $46,66 \%$ atau hamper setengahnya jamaah memiliki penerimaan yang kurang baik terhadap kegiatan khutbah jumat tersebut.

Penerimaan jamaah terhadap khutbah jumat menggunakan bahasa arab di Masjid Assuada, penelitian menunjukkan bahwa hampir setengahnya jamaah kurang menerima dengan baik khutbah jumat menggunakan bahasa arab, karena 
jamaah menilai penggunaan bahasa arab dalam khutbah Jumat dirasa kurang sesuai. karena jamaah banyak yang tidak tahu arti dari bacaan khutbah tersebut. Dalam pandangan jamaah lainya, memilih memutuskan mengikuti ibadah Jumat karena adanya suatu hal yang mereka fahami, yakni faktor lokasi dekatnya masjid dengan lingkungan tempat bermukim mereka, karena dalam pemaham mereka menunaikan ibadah Jumat diharuskan ada 40 orang jamaah yang bermukim di sekitar masjid, sehingga mereka menafsirkan bahwa mereka lebih utama menunaikan ibadah Jumat di masjid yang terdekat yakni masjid Assuada, meskipun dalam khutbah Jumatnya mereka tidak bisa memahami apa yang disampaikan khatib.

Kecerdasan beragama adalah Kecerdasan yang berhubungan dengan kualitas beragama pada diri seseoramg. Kecerdasan ini mengarahkan pada diri seseorang untuk berperilaku agama secara benar, sehingga menghasilkan ketaqwaan dan keimanan secara mendalam (Ramayulis 2002 : 79-80).

Dengan demikian aspek kognitif dalam kesadaran beragama akan mengarahkan pada keyakinan terhadap agama, karena dengan kemampuan berfikirnya mereka dapat memilih antara kebenaran dan kesalahan. Sehingga merekapun meenemukan keyakinan atau keimanan sebagai kebutuhan rohaniyahnya demi ketentraman jiwanya. Karena dengan mengenal dan mendekatkan diri kepada Allah, maka jiwa seseorang akan terlindungi dan bahagia.

Sehingga dapat ditarik kesimpulan dari diagram yang sudah dipaparkan bahwa hamper setengahnya jamaah memiliki penerimaan yang kurang baik terhadap kegiatan khutbah jumat tersebut. Salah satu bentuk dari penyesuaian diri adalah aktif bermain dengan teman sebayanya. Pertama ia berperan sebagai penonton saja, kemudian ia bermain sendiri, tahap bermain sendiri dilewatinya lalu ia bergabung untuk bermain dengan teman sebayanya.

Dalam masyarakat, seseorang akan melaksanakan interaksi sosial dengan teman sebayanya atau anggota masyarakat lainnya. Apabila teman sepergaulan itu menampilkan perilaku yang sesuai dengan nilai-nilai agama (berakhlak baik) maka mereka pun cenderung akan berakhlak baik. Begitu sebaliknya, apabila teman sepergaulan menampilkan perilaku yang kurang baik, amoral, bahkan melanggar norma-norma agama, maka mereka akan cenderung terpengaruh untuk mengikuti perilaku tersebut.

\section{PENUTUP}

Dari hasil penelitian yang telah diperoleh, mengacu pada Teori S-O-R (Stimulus - Organisme - Respons) responden memiliki kecenderungan kurang menerima dengan baik terhadap khutbah jumat menggunakan Bahasa Arab yang disampaikan oleh khotib.. Hal ini dapat dibuktikan dengan angket yang disebar serta melalui observasi dan wawancara, dapat diperoleh hasil yang sebagian besar 
jamaah Masjid Assuada tidak dapat memahami dengan baik pesan-pesan dari khotib yang disampaikan selama ini.

Berdasarkan pembahasan yang sudah dijabarkan, dapat disimpulkan bahwa : Dari Segi Perhatian jamaah terhadap khutbah jumat menggunakan bahasa arab di Masjid Assuada lebih dari setengahnya memperhatikan khutbah jumat. Hal ini disebabkan karena jamaah merasa membutuhkan apa yang di sampaikan oleh khotib, serta jamaah mengetahui bahwa mengikuti dan mendengarkan khutbah jumat merupakan salah satu syarat shalat jumat, walaupun sebagian jamaah yang tidak memberikan perhatian yang serius di karenakan tidak mengerti apa yang sampaikan oleh khotib. jamaah mengaku mengantuk pada saat berlangsungnya khutbah jumat serta jamaah juga asik mengobrol karena merasa bosan. Tapi sebagian besar jamaah yang mengantuk dan mengobrol, kemudian kembali berusaha berkonsentrasi dan tidak menganggu jamaah yang lainnya

Dari segi Pemahaman jamaah terhadap khutbah jumat menggunakan bahasa arab di Masjid Assuada, disimpulkan bahwa jamaah lebih dari setengahnya tidak memahami materi khutbah jumat yang disampaikan oleh khotib. Hal ini di karenakan pemahaman jamaah terhadap khutbah jumat menggunakan bahasa Arab yaitu rendah karena banyak masyarakat yang tidak paham tentang bahasa arab dan tidak menggunakan bahasa arab dalam kehidupan sehari-hari, serta menggunakan bahasa arab kurang dapat di pahami oleh sebagian besar jamaah shalat jumat, sehingga materi yang di sampaikan oleh khotib tidak dapat di pahami dengan baik.

Hal tersebut dapat dilihat dalam hasil temuan data mengenai keputusan yang diambil jamaah untuk menunaikan ibadah Jumat dan mendengarkan khutbah Jumat, meskipun semua jamaah mengaku tidak faham secara keseluruhan apa isi dari khutbah yang disampaikan oleh khatib, seperti jamaah anak-anak, mereka tidak mengetahui sama sekali arti dari khutbah Jumat tersebut, lain halnya dengan jamaah dewasa mereka sebagian besar mengetahui arti dari khutbah, namun hanya pada garis besarnya saja, seperti perintah untuk bertaqwa namun untuk materi yang disampaikan oleh khatib mereka tidak begitu paham dengan apa yang disampaikan dalam khutbah tersebut

Dari segi Penerimaan jamaah terhadap khutbah jumat menggunakan bahasa arab di Masjid Assuada, penelitian menunjukkan bahwa hampir setengahnya jamaah kurang menerima dengan baik khutbah jumat menggunakan bahasa arab, karena jamaah menilai penggunaan bahasa arab dalam khutbah Jumat dirasa kurang sesuai. karena jamaah banyak yang tidak tahu arti dari bacaan khutbah tersebut. Dalam pandangan jamaah lainya, memilih memutuskan mengikuti ibadah Jumat karena adanya suatu hal yang mereka fahami, yakni faktor lokasi dekatnya masjid dengan lingkungan tempat bermukim mereka, karena dalam pemaham mereka menunaikan ibadah Jumat diharuskan ada 40 orang jamaah yang bermukim di sekitar masjid, sehingga mereka menafsirkan bahwa mereka lebih utama menunaikan ibadah Jumat di masjid yang terdekat yakni masjid Assuada, meskipun dalam khutbah Jumatnya mereka tidak bisa memahami apa yang disampaikan khatib. 
A. K. Sandi, D. Suherdiana, \& M. Khoyin

\section{DAFTAR PUSTAKA}

Agustina. L, 2004) Sosiolinguistik Perkenalan Awal, Jakarta PT Rineka Cipta

Busyairi. M (1994) Metodologi Pengajaran Bahasa Arab. Sumbangsih Offset, Yogyakarta

Effendy.O, (2003) Ilmu, teori dan filsafat komunikasi. Citra Aditya Bakti, Bandung Effendy.O. (1989) Kamus Komunikasi . PT.Mandar Maju, Bandung Muhammad Khalil,(2003) Khutbah-khutbah Rasulullah, Darul Falah Romli.A, (1996) Publication information, Pustaka Progresif, Surabaya

Suharsimi.A, (2006) prosedurpenelitian suatu pendekatan praktik. Rineka Cipta, Jakarta Rakhmat.J, (2005) Psikologi Komunikasi. PT.Remaja Rosdakarya, Bandung Syafaat Habib. M, (1992) Pedoman Dakwah dan Khutbah, Widjaya, Jakarta Sulaiman.R, (1992) Fiqh Islam, CV.Sinar Baru, Bandung 1992

Saepuloh.U, (2009) Model Komunikasi Dakwah Jamaah Tabligh. dalam Ilmu Dakwah: Academic Journal for Homiletic Studies, 4(14), 671-672 